\title{
Retrospective Evaluation of Pediatric Patients With Abdominal Tuberculosis: A Single Center Experience
}

\author{
Abdominal Tüberküloz Tanılı Çocuk Hastaların Retrospektif Olarak \\ Değerlendirilmesi: Tek Merkez Deneyimi
}

\author{
Sevgi Yaşar Durmuş'(iD), Gönül Tanır'(iD), Ayşe Seçil Ekşioğlu²(iD), Türkan Aydın Teke'(iD), Yasemin Taşçı Yıldız²(iD), \\ Ayşe Kaman'(iD), Rumeysa Yalçınkaya'(iD), Nilüfer Arda(iD), Fatma Nur Öz'(iD) \\ ${ }^{1}$ Clinic of Pediatric Infectious Diseases, Ankara Dr. Sami Ulus Maternity and Children Research and Training Hospital, Ankara, Turkey \\ ${ }^{2}$ Clinic of Radiology, Ankara Dr. Sami Ulus Maternity and Children Research and Training Hospital, Ankara, Turkey \\ ${ }^{3}$ Clinic of Pathology, Ankara Dr. Sami Ulus Maternity and Children Research and Training Hospital, Ankara, Turkey
}

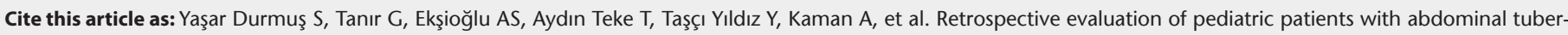
culosis: a single center experience. J Pediatr Inf 2020;14(4):e204-e211.
\end{abstract}

Abstract

Objective: Abdominal tuberculosis is a kind of extrapulmonary tuberculosis that can usually occur during the lymphohematogenous spread of first Mycobacterium tuberculosis infection, develop by neighborhood from an abdominal focus or a mesenteric lymph node. The aim of this study is to evaluate pediatric cases diagnosed with abdominal tuberculosis.

Material and Methods: Between 2012-2018, seven patients diagnosed with abdominal tuberculosis through patients who diagnosed with extrapulmonary tuberculosis in our hospital, were included in study. Demographic and clinical characteristics, diagnostic methods, commenced treatments and clinical follow up of patients were listed from medical records.

Results: Of patients, four were female. The mean age was $144.2 \pm 42.7$ months. None of the patients had a history of tuberculosis contact. The median complaint time was 20 days (5-180). The most frequent complaint was abdominal pain and the most frequent physical examination finding was abdominal tenderness. Mean white blood cell count was $9.26 \times 10^{3} \pm 4.77 \times 10^{3} \mu / \mathrm{L}, \mathrm{C}$ reactive protein level: $79.9 \pm 54.9 \mathrm{mg} / \mathrm{dL}$, erytrocyte sedimentation rate: $45 \pm 30 \mathrm{~mm} / \mathrm{h}$. Tuberculin skin test was positive in two patients, interferon gamma releasing assay was positive in three patients, and in two patients, both tests were positive. There were findings suggesting tuberculosis on pulmonary imaging in five patients and abdominal imaging in all patients. Histopathological examination of
Öz

Giriş: Abdominal tüberküloz, genellikle Mycobacterium tuberculosis ile ilk enfeksiyonun lenfohematojen yayılımı sırasında veya bir abdominal odak, mezenterik lenf bezinden komşuluk yoluyla gelişen bir ekstrapulmoner tüberküloz çeşididir. Bu çalışmada, abdominal tüberküloz tanısı olan çocuk olguların değerlendirilmesi amaçlanmıştır.

Gereç ve Yöntemler: Çalışmaya hastanemizde 2012-2018 tarihleri arasında ekstrapulmoner tüberküloz tanısı alan hastalar içinden abdominal tüberküloz tanısı alan 7 hasta dahil edildi. Tıbbi kayıtlardan hastaların demografik ve klinik özellikleri, uygulanan tanısal yöntemler, başlanan tedaviler ve klinik izlemleri kaydedildi.

Bulgular: Hastaların dördü kızdı. Ortalama yaş 144.2 ay \pm 42.7 aydı. Hastaların hiçbirinde tüberküloz teması öyküsü yoktu. Hastaların yakınma süreleri ortanca 20 (5-180) gündü. En sık yakınma karın ağrısı, en sık fizik inceleme bulgusu abdominal hassasiyetti. Hastaların başvurudaki ortalama beyaz küre sayısı, $9.26 \times 10^{3} \pm 4.77 \times 10^{3} \mu / \mathrm{L}, \mathrm{C}$ reaktif protein $79.9 \pm 54.9$ $\mathrm{mg} / \mathrm{dL}$, eritrosit sedimentasyon hızı $45 \pm 30 \mathrm{~mm} / \mathrm{saat}$ idi. Tüberkülin cilt testi iki hastada, interferon gama salınım testi üç hastada pozitifken, her iki testin de pozitif olduğu iki hasta vardı. Beş hastanın pulmoner görüntülemesinde ve tüm hastaların abdominal görüntülemesinde tüberküloz düşündüren bulgular mevcuttu. Altı hastadan alınan örneklerin histopatolojik incelemesinde tüberküloz ile uyumlu bulgular saptandı. Üç hastadan alınan klinik örneklerde mikrobiyolojik olarak $M$. tuberculosis varlığı doğrulandı. En sık abdominal tüberküloz tipi mezenterik lenfadenitti. Baş-

Correspondence Address/Yazışma Adresi

Sevgi Yaşar Durmuş

Ankara Dr. Sami Ulus Kadın Doğum,

Çocuk Sağlığı ve Hastalıkları Eğitim ve Araştırma Hastanesi,

Çocuk Enfeksiyon Hastalıkları Kliniği,

Ankara-Türkiye

E-mail: drsvgysr@gmail.com

Received: 03.01 .2020

Accepted: 02.02 .2020

Available Online Date: 18.12.2020

OCopyright 2020 by Pediatric Infectious Diseases and Immunization Society. Available online at www.cocukenfeksiyon.org 
the specimens of six patients revealed findings consistent with tuberculosis. The presence of $M$. tuberculosis was confirmed microbiologically in clinical specimens taken from three patients. The most common abdominal tuberculosis type was mesenteric lymphadenitis. The mean time from admission to diagnosis was $15 \pm 12.8$ days. All patients recieved antituberculosis treatment.

Conclusion: Abdominal tuberculosis should be kept in mind, in patients presenting with abdominal complaints lasting more than five days. UItrasonography and computed tomography are useful to determine abdominal tuberculosis type. The disease can be sucsessfully treated with standart antituberculosis treatment.

Keywords: Abdominal tuberculosis, child, Mycobacterium tuberculosis

\section{Introduction}

Tuberculosis (TB) is one of the most frequently encountered infections estimated to affect one in every three people worldwide annually. In the 2018 Global TB report of the World Health Organization (WHO), TB incidence in the world was reported as $142 / 100.000(1,2)$. TB incidence in our country has declined to $14.6 / 100.000$ today while it was $64.8 / 100.000$ in 1985. It is estimated that 1 million new pediatric cases occur every year $(1,2)$. Abdominal TB in children has been reported to constitute $0.3 \%-4.3 \%$ of childhood TB cases $(3,4)$. Abdominal TB usually develops during the lymphohematogenous spread of the first infection with M. tuberculosis or through an abdominal source or neighborhood from the mesenteric lymph node. Rarely, it can develop by swallowing the infected sputum or consuming contaminated milk. Mesenteric lymph node, the peritoneum, gastrointestinal tract or intraabdominal solid organs such as the liver, spleen, adrenal glands and pancreas can also be affected in abdominal TB (5). Delay in diagnosis is caused by the nonspecific nature of the symptoms and findings of the disease $(3,6)$. Histopathological investigation of the sample taken by laparotomy or observation of the regression of the symptoms with anti-TB therapy are required for abdominal TB diagnosis $(3,7)$. This study aimed to retrospectively evaluate the demographic and clinical features of our abdominal TB cases, the diagnostic methods performed, and treatments and their outcomes.

\section{Materials and Methods}

Our hospital is one of the reference hospitals in terms of childhood tuberculosis where 157 children diagnosed with TB and 670 children diagnosed with latent TB infection were followed during 2012-2018. This study included 7 abdominal TB cases out of 29 cases diagnosed with extrapulmonary tuberculosis in the Pediatric Infectious Diseases Clinic of our hospital between 2012 and 2018. Retrospectively, the study recorded data regarding the age and sex of the cases, presence of another disease, status of Bacille Calmette-Guerin (BCG) vaccination, tuberculosis contact, complaints on presentation, length of the complaints, physical examination findings, preliminary vurudan tanı konulana kadar geçen ortalama süre 15 gün \pm 12.8 gündü. Tüm hastalar antitüberküloz tedavi aldı.

Sonuç: Beş günden uzun süren abdominal yakınmalarla başvuran hastalarda abdominal tüberküloz akılda bulundurulmalıdır. Ultrasonografi ve bilgisayarlı tomografi hastalığın tipinin saptanmasında yararlıdır. Standart antitüberküloz tedavi ile hastalık başarı ile tedavi edilebilir.

Anahtar Kelimeler: Abdominal tüberküloz, çocuk, Mycobacterium tuberculosis

diagnosis as a result of presentation evaluation, time elapsed between admission and diagnosis, complete blood count on presentation, levels of C-reactive protein (CRP) and erythrocyte sedimentation rate (ESR), the results of tuberculin skin test (TST) and interferon gamma release assay (IGRA), radiologic findings, the result of histopathological examination, if present, acid-resistant bacteria (ARB), M. tuberculosis culture and polymerase chain reaction results and clinical observation.

Tuberculin skin test (TST) was performed by the intradermal injection of purified protein derivative (PPD) of 5 tuberculin units. The widest diameter of the induration measured 72 hours after the test was accepted positive as $\geq 10 \mathrm{~mm}$ in cases without BCG vaccination and as $\geq 15 \mathrm{~mm}$ in cases without $B C G$ vaccination (8). Interferon gamma release assay was performed according to the recommendation of the manufacturer (QuantiFERON-TB Gold Plus QFT-Plus (Qiagen, Germany)). Abdominal ultrasonography (USG) and abdominal computed tomography (CT) were evaluated by the pediatric radiologists of our hospital. Positron emission tomography (PET) was interpreted by the nuclear medicine specialists of our hospital.

Diagnosis of abdominal TB was made (1) if direct ARB and/ or M. tuberculosis culture positivity was established in an intraabdominal clinical sample, (2) upon detecting granulomatous inflammation and/or granulomatous inflammation $+\mathrm{ca}-$ seification necrosis + TST or IGRA positivity or (3) confirming finding suggestive of TB in abdominal imaging + TST or IGRA positivity, and (5) considering TB according to WHO diagnostic criteria and receiving response to anti-TB treatment $(3,9,10)$.

\section{Statistical Analysis}

SPSS 20.0 for Windows was used for statistical analysis. Descriptive statistics was performed for demographic data. Mean \pm standard deviation was calculated for the variables determined by measures and percentages (\%) and frequency values were calculated for the variables determined by counting. Local ethics committee approval was received for the study.

\section{Results}

Mean age of the abdominal tuberculosis 7 patients, 4 females and 3 males, was found as 144.2 months \pm 42.7 months 
(range: 83 months-201 months). None of the patients had a history of tuberculosis contact. Four of the patients had received Bacille Calmette-Guerin vaccination. BCG vaccination status could not be reached in three patients. One patient had familial Mediterranean fever, one had hypothyroidism and type 1 diabetes mellitus, one had bilateral hydronephrosis, and one had growth hormone deficiency. There was no accompanying disease in three patients. Table 1 summarizes the complaints of the patients during presentation, their physical examination findings, preliminary diagnoses, TST and IGRA results, and time elapsed until receiving abdominal TB diagnosis, Table 2 shows histopathological and microbiological findings, Table 3 indicates imaging findings, and Table 4 shows abdominal TB type. Imaging findings of case 5 and 7 are shown on Images 1 and 2. Median length of patient complaints was 20 days (range: 5-180 days), and mean duration from admission to diagnosis was found as 15 days \pm 12.8 days. Mean peripheral white blood cell count, CRP and ESR of the patients on presentation were detected respectively as $9.26 \mathrm{x}$ $10^{3} \pm 4.77 \times 10^{3} / \mu \mathrm{L}, 79.9 \pm 54.9 \mathrm{mg} / \mathrm{L}, 45 \pm 30 \mathrm{~mm} / \mathrm{h}$.

As antituberculosis treatment, isoniazid $(\mathrm{H})$, rifampisin $(R)$, ethambutol $(E)$ and pyrazinamide $(Z)$ were started for the first 2 months during the intensive phase according to the 2011 Tuberculosis Diagnosis and Treatment Guideline of the Ministry of Health, Turkey. Isoniazid and rifampisin were used during the continuation phase for 4 months (8). Upon confirming pyrazinamide resistance in patient 7 , streptomycin was initiated by stopping pyrazinamide. Treatment of four of

Table 1. Complaints, physical examination findings, preliminary diagnoses, time elapsed until diagnosis, TST and IGRA results of the patients with abdominal TB*

\begin{tabular}{|c|c|c|c|c|c|c|c|c|}
\hline Patient & $\begin{array}{c}\text { Complaints on } \\
\text { presentation }\end{array}$ & $\begin{array}{c}\text { Age } \\
\text { (months) }\end{array}$ & $\begin{array}{l}\text { Length of the } \\
\text { complaints (days) }\end{array}$ & $\begin{array}{c}\text { Physical examination } \\
\text { findings }\end{array}$ & $\begin{array}{l}\text { Preliminary } \\
\text { Diagnosis }\end{array}$ & TST & IGRT & $\begin{array}{c}\text { Time elapsed } \\
\text { until diagnosis }\end{array}$ \\
\hline 1 & Abdominal pain & 159 & 7 & $\begin{array}{c}\text { Abdominal } \\
\text { tenderness, } \\
\text { palpable mass }\end{array}$ & $\begin{array}{c}\text { Acute } \\
\text { appendicitis }\end{array}$ & Positive & Negative & 42 days \\
\hline 2 & $\begin{array}{l}\text { Abdominal pain and } \\
\text { weight loss }\end{array}$ & 192 & 180 & Normal & $\mathrm{IBD} \mathrm{D}^{*}$ & Positive & Positive & 11 days \\
\hline 3 & $\begin{array}{l}\text { Abdominal pain and } \\
\text { growth and } \\
\text { developmental delay }\end{array}$ & 138 & 20 & Normal & $\begin{array}{l}\text { Abdominal } \\
\text { pain etiology }\end{array}$ & Positive & Positive & 14 days \\
\hline 4 & Fever, weight loss & 83 & 45 & $\begin{array}{c}\text { Abdominal } \\
\text { tenderness, palpable } \\
\text { mass }\end{array}$ & $\begin{array}{l}\text { Acute ap- } \\
\text { pendicitis }\end{array}$ & Unknown & Positive & 7 days \\
\hline 5 & $\begin{array}{c}\text { Fever, weight loss, } \\
\text { vomiting }\end{array}$ & 110 & 15 & $\begin{array}{c}\text { Extensive abdominal } \\
\text { tenderness }\end{array}$ & lleus & Negative & Positive & 2 days \\
\hline 6 & Abdominal pain & 201 & 5 & Abdominal distension & Lymphoma & Positive & Positive & 17 days \\
\hline 7 & $\begin{array}{l}\text { Fever, Abdominal } \\
\text { pain }\end{array}$ & 127 & 60 & $\begin{array}{c}\text { Abdominal } \\
\text { tenderness, } \\
\text { hepatosplenomegaly }\end{array}$ & Lymphoma & Negative & Positive & 12 days \\
\hline
\end{tabular}

Table 2. Microbiological and histopathological findings of the patients with abdominal TB *

\begin{tabular}{|l|c|c|c|c|c|}
\hline Patient & Site of sample retrieval & ARB* & Mycobacteria culture & $\begin{array}{c}\text { Mycobacteria } \\
\text { PCR }^{*}\end{array}$ & Histopathological finding \\
\hline 1 & No microbiological sample & No & Could not be performed & $\begin{array}{c}\text { Could not be } \\
\text { performed }\end{array}$ & Necrotizing granulomatous inflammation \\
\hline 2 & Intraabdominal & Negative & No growth & Positive & Caseous granulomatous inflammation \\
\hline 3 & Fasting gastric juice & Positive & No growth & Negative & No biopsy \\
\hline 4 & $\begin{array}{r}\text { Fasting gastric juice, } \\
\text { intraabdominal }\end{array}$ & Negative & No growth & Positive & $\begin{array}{c}\text { Granulomatous inflammation, Bacilli was } \\
\text { seen in \#EZN staining }\end{array}$ \\
\hline 5 & Fasting gastric juice & Negative & No growth & Negative & Necrotizing granulomatous inflammation \\
\hline 6 & Intraabdominal & Negative & No growth & Negative & Caseous granulomatous inflammation \\
\hline 7 & Intraabdominal & Positive & Pyrazinamide resistant & Positive & $\begin{array}{c}\text { Caseous granulomatous inflammation } \\
\text { Bacilli was seen in \#EZN staining }\end{array}$ \\
\hline *See the text for abbreviations, \#EZN: Ehrlich Ziehl Neelsen. & &
\end{tabular}


Table 3. Findings of chest X-ray, thoracic CT, abdominal USG and abdominal CT of the patients *

\begin{tabular}{|c|c|c|c|c|}
\hline Patient no & Chest X-ray & Thoracic $\mathrm{CT}^{*}$ & Abdominal USG* & Abdominal $\mathrm{CT}^{*}$ \\
\hline 1 & Normal & Not performed & $\begin{array}{c}\text { Appendicoliths with calcification? } \\
\text { Mesenteric inflammation }\end{array}$ & Not performed \\
\hline 2 & $\begin{array}{l}\text { Milimetric nodule on the left } \\
\text { lung } \\
\text { Linear density increase in the } \\
\text { right lung apex }\end{array}$ & $\begin{array}{l}\text { Nodular lesions in both } \\
\text { lungs Primary pulmonary } \\
\qquad \mathrm{BB}^{*} \text { ? }\end{array}$ & $\begin{array}{l}\text { Inflammatory wall thickening in } \\
\text { the ascending colon and cecum } \\
\text { Mesenteric lymph nodes } \\
\text { Minimal free fluid }\end{array}$ & $\begin{array}{c}\text { Inflammatory wall thickening in the } \\
\text { ascending colon, cecum and hepatic } \\
\text { flexura } \\
\text { Edema in the ileocecal valve } \\
\text { Stenosis in the lumen proximal to the } \\
\text { ascending colon } \\
\text { Mesenteric lymph nodes }\end{array}$ \\
\hline 3 & $\begin{array}{c}\text { Bilateral perihilar, paracardiac, } \\
\text { peribronchial infiltration, } \\
\text { increase in aeration }\end{array}$ & Nodule in the right lung & $\begin{array}{l}\text { Hepatomegaly } \\
\text { Minimal free fluid }\end{array}$ & $\begin{array}{l}\text { Wall thickening on the colon and the } \\
\text { appendix }\end{array}$ \\
\hline 4 & Normal & Normal & $\begin{array}{c}\text { Hepatomegaly } \\
\text { Abscess about } 5 \mathrm{~cm} \text { in diameter } \\
\text { on the right lower quadrant and } \\
\text { adjacent necrotizing lymph node, } \\
\text { Mesenteric inflammation, } \\
\text { Multiple mesenteric lymph nodes }\end{array}$ & $\begin{array}{c}\text { Mucosal edema on jejunal walls } \\
\text { Inflammatory wall thickening on distal } \\
\text { ileal walls and adjacent } 5.5 \times 5 \times 5 \mathrm{~cm} \\
\text { abscess } \\
\text { Mesenteric inflammation, } \\
\text { Multiple mesenteric lymph nodes }\end{array}$ \\
\hline 5 & $\begin{array}{l}\text { Bilateral hilar distension, } \\
\text { infiltration }\end{array}$ & $\begin{array}{l}\text { Mediastinal lymph nodes } \\
\text { Nodules milimetric in size in } \\
\text { both lungs and consolidati- } \\
\text { on fields, budded tree view, } \\
\text { increase in wall thickening } \\
\text { in the lower end of the } \\
\text { esophagus }\end{array}$ & $\begin{array}{c}\text { Free fluid } \\
\text { Increase in mesenteric echo and } \\
\text { thickness Edema in the bowels, } \\
\text { loss of peristaltism compatible } \\
\text { with the ileus } \\
\text { Mesenteric lymph nodes } \\
\text { Locular collection } 3.5 \mathrm{~cm} \text { in } \\
\text { diameter in the right hypochon- } \\
\text { drium }\end{array}$ & $\begin{array}{c}\text { Hepatosplenomegaly } \\
\text { Wall thickening in the jejunal ve ileal } \\
\text { segments, terminal ileum, and sigmoid } \\
\text { colon } \\
\text { Mesenteric inflammation } \\
\text { Free fluid }\end{array}$ \\
\hline 6 & Bilateral hilar distension & $\begin{array}{l}\text { Millimetric mediastinal } \\
\text { lymph nodes } \\
\text { Extensive millimetric ground } \\
\text { glass infiltrations on both } \\
\text { lungs } \\
\text { Millimetric thickening of } \\
\text { the pleural with dispersed } \\
\text { localizations }\end{array}$ & $\begin{array}{l}\text { Hepatosplenomegaly } \\
\quad \text { Free fluid } \\
\text { Omental thickening }\end{array}$ & $\begin{array}{c}\text { Free fluid } \\
\text { Omental thickening } \\
\text { Calcified mesenteric lymph nodes } \\
\text { Edema in jejunal and ileal walls } \\
\text { PET/CT*: Irregular increase in intraab- }_{\text {dominal free fluid and accompanying }} \\
\text { peritoneal nodules FluoroDoexiGluco- } \\
\text { se (FDG)involvement } \\
\text { Tuberculosis peritonitis? Malignancy? }\end{array}$ \\
\hline 7 & $\begin{array}{c}\text { Bilateral perihilar, peribron- } \\
\text { chial infiltration Increase in } \\
\text { aeration }\end{array}$ & $\begin{array}{l}\text { Millimetric mediastinal } \\
\text { lymph nodes } \\
\text { Millimetric infiltration sites } \\
\text { with irregular margins on } \\
\text { the left lung }\end{array}$ & $\begin{array}{c}\text { Periportal echogenity increase } \\
\text { Parenchymal heterogeneous } \\
\text { appearance on liver } \\
\text { Splenomegaly } \\
\text { Multiple mesenteric lymphade- } \\
\text { nopathy } \\
\text { Two cystic lesions with dense } \\
\text { content and thick wall in the } \\
\text { lower abdomen (about } 8 \times 7 \times 6.5 \\
\text { cm and } 6 \times 5 \times 4.5 \mathrm{~cm} \text { ) } \\
\text { (Abscess? Infected Lymphatic } \\
\text { Malformation??) }\end{array}$ & $\begin{array}{c}\text { Periportal edema, } \\
\text { Splenomegaly } \\
\text { Perihepatic minimal free fluid } \\
\text { Perivesical edema } \\
\text { Mesenteric inflammation } \\
\text { Multiple mesenteric lymphadenopathy } \\
\text { Three cystic-necrotic mass lesions with } \\
\text { peripheral contrast involvement and } \\
\text { lobular contour located in the lower } \\
\text { abdomen (Primarily abscessed TB* } \\
\text { lymphadenitis?) }\end{array}$ \\
\hline
\end{tabular}

the patients was completed in our hospital, and the treatment of the rest was completed in other centers. None of the patients was deceased.

\section{Discussion}

Abdominal TB ranks sixth in prevalence among the extrapulmonary TB cases (11). Thirty-four cases have been de- 
Table 4. Abdominal TB type*

\begin{tabular}{|l|l|}
\hline Patient no & Abdominal TB* type \\
\hline 1 & Colorectal \\
\hline 2 & Colorectal, Mesenteric lymphadenitis \\
\hline 3 & Colorectal \\
\hline 4 & Jejunal and Ileocecal, Mesenteric lymphadenitis \\
\hline 5 & Jejunal and Ileocecal, Colorectal, Mesenteric lymphadenitis \\
\hline 6 & Jejunal and Ileocecal, Mesenteric lymphadenitis, Omental thickening, Adhesive peritonitis \\
\hline 7 & Liver, Mesenteric lymphadenitis, Adhesive peritonitis \\
\hline$*$ See the text for abbreviations. & \\
\hline
\end{tabular}

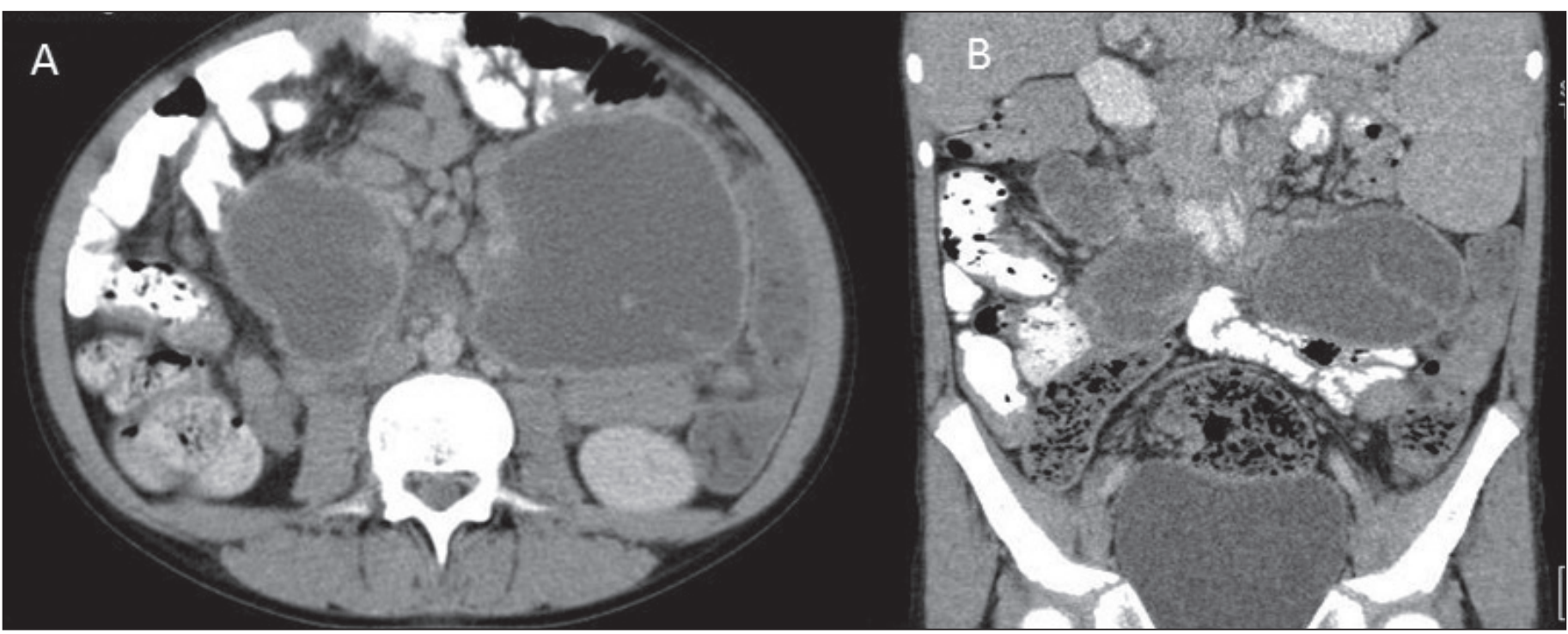

Figure 1. A-B. Multiple abscess formations seen in the abdomen of an 11-year-old patient with abdominal tuberculosis involvement. Contrast abdominal CT investigation A. Axial image B. Coronal reformat.

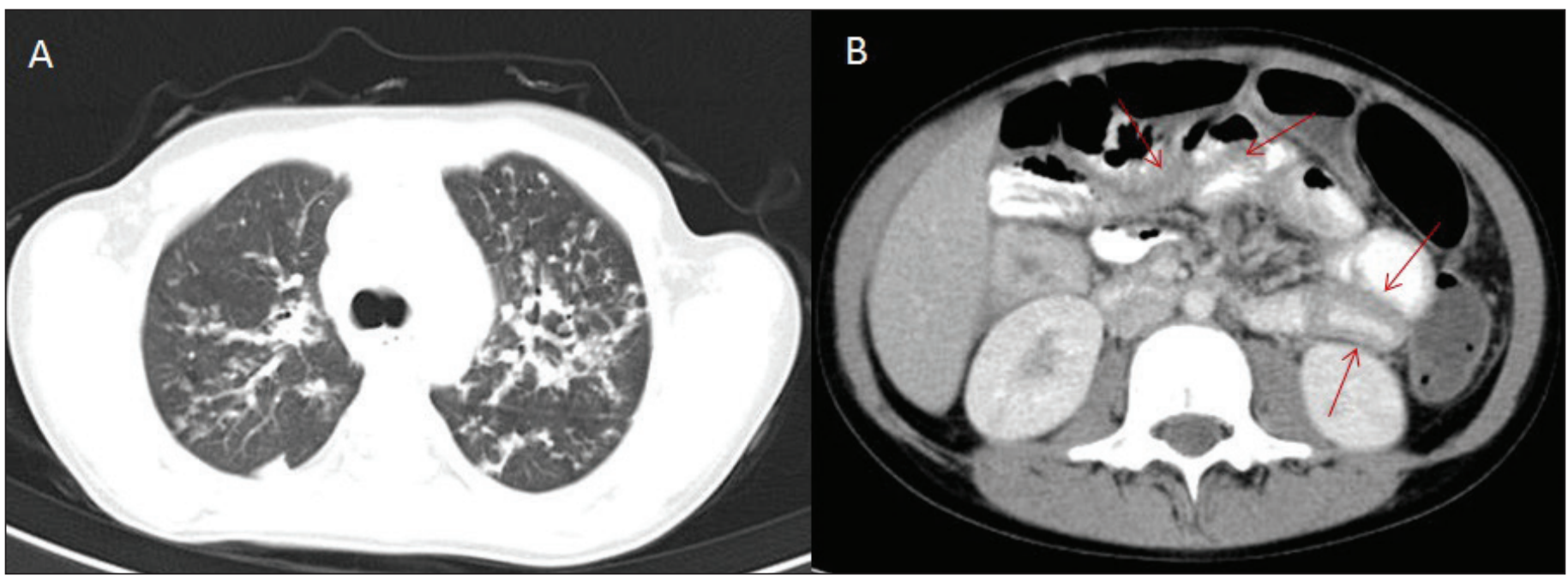

Figure 2. A. Active tuberculosis involvement manifesting a 'budded tree' view on the thoracic CT of a 9-year-old female patient. B. Thickening is seen partly in bowel segments (arrows) on the abdominal CT scan of the same patient with oral and IV contrast material. Moreover, edema-related calcification in the mesentery and multiple mesenteric lymph nodes, milimetric in size, attract attention. 
tected in a retrospective, single-center study from Turkey evaluating children with abdominal TB in a 25 -year period (4). Abdominal TB prevalence has been found as $4.3 \%$ and to be more frequently encountered compared to developed countries $(0.3 \%)$ in a 12 -year, multi-center study investigating childhood tuberculosis in our country $(3,12)$. In an abdominal TB series including 6 pediatric cases from Canada, it has been reported that abdominal TB was seen at a rate of $4 \%$ among all patients admitted to hospital for TB and that the reason why this rate was higher than that reported from the USA was attributed to the fact that only patients admitted to the hospital were included into the study (3). This rate was found similar in our study with $4.4 \%$ since we also studied patients admitted to hospital. It has been reported that childhood abdominal TB cases are commonly seen in the age range of 6-11 years (13). In our study, mean age of the patients was found as 12 years, similar to the aforementioned study.

Since findings of abdominal TB are nonspecific during admission, it has been reported that being diagnosed even in regions with high TB incidence is late (3). It has been seen in various studies covering children with abdominal TB that this delay in diagnosis can last between 1 month and 6 years (14). Our study determined that the cases being diagnosed in an average of 15 days after first presentation. The reason why the length of being diagnosed for the $4^{\text {th }}$ and $5^{\text {th }}$ patients in our series was 7 days and 2 days shorter respectively was the fact that they had been operated on with a preliminary diagnosis of acute abdomen in another center and samples had been taken for histopathological examination. The most commonly reported complaints in the series covering children with abdominal TB include abdominal distension, ascites, abdominal pain, fever, and weight loss $(3,4)$. The most frequently observed complaint on presentation in our study was abdominal pain, which was accompanied by fever, weight loss, and growth and developmental delay, respectively. Median length of complaints in our study was found as 20 days (5-180 days). It was considered that investigating abdominal TB is important in patients presenting with long term abdominal complaints in our country where tuberculosis prevalence is still $14.6 / 100.000$.

It is recommended to put in maximum effort for the microbiological diagnosis of patients suspected of abdominal TB (3). The diagnosis was made histopathologically in 6 of the 7 patients comprising our case series, and microbiological confirmation was received in three of these patients (patients 2, 4 and 7). The diagnosis was made with abdominal CT and IGRA positivity in the $5^{\text {th }}$ and $6^{\text {th }}$ patients in whom microbiological confirmation could not be established. One patient whose microbiological sampling could not be carried out was the patient that had been operated for acute appendicitis and had presented with a histopathology result (Patient 1). One patient in whom biopsy was not performed (Patient 3) diagnosed with abdominal tuberculosis by ARB positivity in fasting gastric juice and findings suggestive of TB on chest $X$-ray and abdominal CT and TST positivity. Rates of microbiological confirmation are different in pediatric series of abdominal TB. In a childhood abdominal TB series including 38 patients, definitive microbiological diagnosis has been reported to be made in $47 \%$ of the patients (15). In a retrospective study including 115 pediatric cases with abdominal TB in conducted in India between January 1999 and December 2004, microbiological confirmation was found as $33 \%$ (14). In a study conducted in Taiwan between January 1998 and December 2002, M. tuberculosis has been detected by culture and/or PCR in 10 patients receiving abdominal TB diagnosis (6). In an abdominal TB study conducted in Taiwan between 1995 and 2008 with 13 pediatric cases, microbiological confirmation was achieved in three patients (14). In a pediatric abdominal TB series with 35 cases from Turkey and in another series with 8 cases, it has been reported that microbiological confirmation was achieved in five and three patients, respectively $(11,16)$.

Abdominal TB has five signs including lymphadenitis, peritonitis, gastrointestinal tract involvement, mesenteric/omental inflammation and hepatosplenomegaly. According to the site of involvement, gastrointestinal TB is classified as esophageal, gastric, duodenal, ileocecal, and colorectal TB. Generally, various combinations of these findings occur in one patient $(17,18)$. Abdominal TB types commonly reported in children and adults are mesenteric lymphadenitis and fibrotic peritonitis in children and gastrointestinal tract involvement in adults (18). Lymphadenopathy could be single or grouped, calcified or not. Extensive peritoneal involvement occurs rarely and generally as a part of disseminated TB. Peritoneal TB can be ascitic (wet) or adhesive (fibrotic or dry). Ascitic type is seen more commonly in adults and adhesive type in children. Gastrointestinal TB is most frequently observed in the ileocecal region. Jejunum involvement is usually seen in patients with ileocecal TB. However, isolated jejunum involvement can occur despite being rare. Isolated colon involvement can develop in mostly the transverse colon or hepatic flexura or the ascending colon. Multifocal involvement has been reported in $28-44 \%$ of the cases. Esophagus, stomach and duodenum TB are rare (18). In five patients in our study, mesenteric lymphadenitis, which is the most common finding of childhood TB, was detected combined with other findings. Jejunal involvement was found along with ileocecal TB in three patients. Isolated colorectal involvement was seen in two patients. lleocecal involvement was accompanied by colorectal involvement in one patient and omental thickening and adhesive peritonitis in another patient. Another patient detected having adhesive peritonitis was the patient with hepatic TB. The most common forms of TB have been reported as TB lymphadenitis in 17 patients, gastrointestinal TB in 10, peritoneal TB in 4, and 
Yaşar Durmuş et al.

TB abscess in one patient in a study investigating 32 pediatric cases with abdominal TB (19). In a study conducted in Tunisia evaluating 13 children with abdominal TB, ascites (wet type peritonitis) has been reported in 9 patients, TB lymphadenitis in 7, spleen nodule in two and liver nodule in one patient (14). In a study from our country investigating 35 children with abdominal TB, it has been reported that 10 patients had ascites, 7 had mesenteric lymphadenitis, 6 had mesenteric, omental thickening, 3 had thickening in intestinal walls, 3 had hepatomegaly, one had splenomegaly, one had abdominal mass, and one had pelvic mass (4). It has been observed in a study including 38 patients that 9 had peritoneal TB, 6 had intestinal TB, 6 had TB lymphadenitis, 3 had disseminated disease, two had granulomatous hepatitis, and 12 patients had more than one form of the disease together (15). In a series evaluating childhood abdominal TB in developed countries, peritoneal form and gastrointestinal form have been detected in three patients each (3). In our series, gastrointestinal form was seen in 6 patients, and the most common form accompanying the gastrointestinal form was mesenteric lymphadenitis. Liver involvement was confirmed in one of our patients as visceral TB. This patient also had mesenteric lymphadenitis and adhesive peritonitis.

For the differential diagnosis of abdominal TB, intraabdominal malignancies, inflammatory bowel diseases (IBD), especially Crohn's disease, and other infectious diseases accompanied by granulomatous inflammation should be kept in mind. Mesenteric lymphadenitis may mimic lymphoma, inflammatory bowel diseases, acquired immunodeficiency syndrome, metastasis or lymphoproliferative disorders. Peritoneal mass, peritoneal carcinomatosis or Burkitt's lymphoma can be confused with cocoon bowel loops caused by fibrotic peritonitis. The fact that bowel wall thickening is eccentric in gastrointestinal TB and generally affects the medial wall of the cecum, and having an exophytic enlargement with the ingestion of the terminal ileum are all compatible with TB rather than Crohn's disease, lymphoma or carcinoma (18). Microbiological confirmation of Mycobacterium tuberculosis makes diagnosis easier (20). In our study, abdominal CT of a patient examined with a preliminary diagnosis of IBD showed colon involvement and mesenteric lymph nodes that could also be seen in Crohn's disease. The patient received definitive diagnosis with $M$. tuberculosis PCR positivity in the peritoneum fluid. In our study, upon showing caseification necrosis histopathologically in a patient suspected of malignancy on PET/ $C T$, the patient received definitive diagnosis with $A R B, P C R$ and culture positivity of the intraabdominal sample of the patient considered to have teratoma on CT.

It was concluded by this study that it is important to investigate abdominal TB in patients presenting with abdominal complaints ongoing for more than 5 days, the type of the dis- ease can be detected by ultrasonography and $\mathrm{CT}$, mesenteric lymphadenitis accompany most TB types, jejunal, ileocecal and colorectal types can occur separately or in conjunction with each other, maximum effort must be put in for microbiological diagnosis, and the disease is successfully treated with the standard 4 anti-TB medications. Small number of cases is the limitation of our five-year series.

Ethics Committe Approval: The ethical approval for this study was obtained from T.C. Ministry of Health Ankara Dr. Sami Ulus Maternity and Children Research and Training Hospital Ethics Committee (Decision no: 2019/3, Date: 15.03.2019).

Informed Consent: Patient consent was obtained.

Peer-review: Externally peer-reviewed.

Author Contributions: Concept - SYD, TAT, GT; Design - SYD, RY, FNÖ; Supervision - GT, ASE, FNÖ; Resource - SYD, AK, GT; Data Collection and/or Processing - SYD, AK, NA, YTY; Analysis and/or Interpretation TAT, ASE, NA, FNÖ; Literature Search - SYD, AK, RY, YTY; Writing - SYD, GT, ASE; Critical Review - All of authors.

Conflict of Interest: No conflict of interest was declared by the authors.

Financial Disclosure: The authors declared that this study has received no financial support.

\section{References}

1. Bingöl A. Tüberkülozun tarihi. In: Özçelik U, Kocabaş E, Ersu R, Gürkan F (eds). Çocukluk Çağında Tüberküloz Tanı, Tedavi ve Korumada Güncel Yaklaşımlar ve Olgu Örnekleri. İstanbul: Nobel Tıp Kitabevleri, 2017;23:1-5. [CrossRef]

2. World Health Organization (WHO). Global tuberculosis report 2018. Geneva: World Health Organization; 2018. [CrossRef]

3. Delisle M, Seguin J, Zeilinski D, Moore DL. Paediatric abdominal tuberculosis in developed countries: case series and literatüre review. Arch Dis Child 2016;101:253-8. [CrossRef]

4. Kılıç Ö, Somer A, Hançerli Törün S, Keser Emiroğlu M, Salman N, Salman $T$, et al. Assessment of 35 children with abdominal tuberculosis. Turk J Gastroenterol 2015;26:128-32. [CrossRef]

5. Özgür Gündeşlioğlu Ö, KocabaşE. Akciğer dışı tüberkülozda klinik özellikler. In: Özçelik U, Kocabaş E, Ersu R, Gürkan F (eds). Çocukluk Çağında Tüberküloz Tanı, Tedavi ve Korumada Güncel Yaklaşımlar ve Olgu Örnekleri. Istanbul: Nobel Tıp Kitabevleri, 2017;23:17-25. [CrossRef]

6. Lin YS, Huang YC, Lin TY. Abdominal tuberculosis in children: a diagnostic challenge. J Microbiol Immunol Infect 2010;43:188-93. [CrossRef]

7. Jullien S, Jain S, Ryan H, Ahuja V. Six-month therapy for abdominal tuberculosis. Cochrane Database Syst Rev 2016;11:CD012163. [CrossRef]

8. Kocabaş E. Çocukluk Çağı Tüberkülozu. In: Akdağ R. (eds). T.C. Sağlık Bakanlığı Tüberküloz Tanı ve Tedavi Rehberi. Ankara: Sağlık Bakanlığı Yayınları, 2011:71-84. [CrossRef]

9. Veeragandham RS, Lynch FP, Canty TG, Collins DL, Danker WM. Abdominal tuberculosis in children: review of 26 cases. J Pediatr Surg 1996;31:170-5. [CrossRef]

10. Donald P, Maher D, Qazi S. A research agenda for childhood tuberculosis. Improving the management of childhood tuberculosis within national tuberculosis programmes: research priorities based on a literature review. Bull World Health Organ 2007;381:1-124. [CrossRef] 
11. Awasthi S, Saxena M, Ahmad F, Kumar A, Dutta S. abdominal tuberculosis: a diagnostic dilemma. J Clin Diagn Res 2015;9:1-3. [CrossRef]

12. Pekcan S, Tana Aslan A, Kiper N, Uysal G, Gürkan F, Patıroğlu T, et al. Multicentric analysis of childhood tuberculosis in Turkey. Turk J Pediatr 2013;55:121-9. [CrossRef]

13. Basu S, Ganguly S, Chandra PK, Basu S. Clinical profile and outcome of abdominal tuberculosis in Indian children. Singapore Med J 2007;48:900-5. [CrossRef]

14. Tinsa F, Essaddam L, Fitouri Z, Brini I, Douira W, Ben Becher S, et al. Abdominal tuberculosis in children. J Pediatr Gastroenterol Nutr 2010;50:634-8. [CrossRef]

15. Malik R, Srivastava A, Yachha SK, Poddar U, Lal R. Childhood abdominal tuberculosis: Disease patterns, diagnosis, and drug resistance. Indian J Gastroenterol 2015;34:418-25. [CrossRef]

16. Usta M, Urganci N, Dalgic N, Uslu-KızIlkan N, Kurtaraner T, Karadag C. A clinical presentation in a series of eight children with abdominal tuberculosis: experience of a single-center in Turkey. Iran J Pediatr 2017;27:16. [CrossRef]
17. Debi U, Ravisankar V, Prasad KK, Sinha SK, Sharma AK. Abdominal tuberculosis of the gastrointestinal tract: revisited. World J Gastroenterol 2014;20:14831-40. [CrossRef]

18. Kritsaneepaiboon S, Andres MM, Tatco VR, Lim CCQ, Concepcion NDP. Extrapulmonary involvement in pediatric tuberculosis. Pediatr Radiol 2017;47:1249-59. [CrossRef]

19. Shah I, Uppuluri R. Clinical profile of abdominal tuberculosis in children. Indian J Med Sci 2010;64:204-9. [CrossRef]

20. Cherif E, Ben Hassine L, Azzabi S, Khalfallah N. Isolated caecal tuberculosis mimicking a neoplastic tumour in an immunocompetent woman. BMJ Case Rep 2013;8:1-2. [CrossRef] 